\title{
ŚWIADOMOŚĆ ZABURZEŃ ROZWOJOWYCH ZE SPEKTRUM AUTYZMU
}

\author{
AWARENESS OF SYMPTOMS OF THE AUTISM SPECTRUM DISORDERS \\ Piotr Poniewierski', Wojciech Strzelecki², Anna Kostiukow', Włodzimierz Samborski \\ ${ }^{1}$ Pracownia Fizjoterapii Reumatologicznej, Klinika i Katedra Reumatologii i Rehabilitacji, Uniwersytet Medyczny im. Karola Marcinkowskiego w Poznaniu \\ ${ }^{2}$ Katedra iZakład Psychologii Klinicznej, Uniwersytet Medyczny im. Karola Marcinkowskiego w Poznaniu \\ DOI: https://doi.org/10.20883/ppnoz.2019.29
}

STRESZCZENIE

Wstęp. Spektrum autyzmu (ASD) jako silnie heterogeniczne, neurorozwojowe zaburzenie, dotyczy deficytów w społecznej komunikacji oraz ograniczonych, powtarzających się wzorcach zachowania, zainteresowania i aktywności.

Cel badania. Ocena poziomu wiedzy dotyczącej objawów autyzmu wśród studentów polskich uczelni.

Materiał. W przeprowadzonym badaniu wzięło udział 446 studentów polskich uczelni wyższych z kierunków pedagogicznych (275 badanych), medycznych (109 osób) i innych (62 osoby). Grupę badaną stanowiło 410 kobiet i 36 mężczyzn w wieku od 18 do 59 lat (średnia wieku 23,92).

Metody. W badaniu użyto kwestionariusz KCAHW (Knowledge About Childhood Autism Among Health Workers) w polskiej wersji językowej, w celu określenia poziomu świadomości autyzmu.

Wyniki. Wykazano, że badani studenci kierunków medycznych (w tym fizjoterapii) osiągają niższe wyniki niż studenci kierunków pedagogicznych. Jednocześnie studenci innych kierunków (takich jak dietetyka) osiągają niższe wyniki niż studenci kierunków medycznych oraz pedagogicznych. Dowiedziono, że studenci kierunków medycznych osiągają niższe wyniki niż studenci kierunków artystycznych oraz pedagogicznych.

Wnioski. Poziom wiedzy o autyzmie wśród studentów polskich uczelni można uznać za niewystarczający. Zwłaszcza wśród studentów kierunków medycznych, czyli wśród przyszłych pracowników związanych bezpośrednio z diagnozą, leczeniem i terapią autyzmu.

Słowa kluczowe: KCAHW, autyzm, ASD, wiedza.

ABSTRACT

Introduction. Autism Spectrum (ASD) as a highly heterogeneous neurodevelopmental disorder concerns deficits in social communication and limited, repetitive patterns of behavior, interest and activity.

Aim of the study. Assessment of the level of knowledge regarding the symptoms of autism among students of Polish universities.

Material. The study involved 446 students of Polish universities in the fields of education (275 respondents), medical (109 people) and others (62 people). The study group consisted of 410 women and 36 men aged 18 to 59 years (average age 23.92).

Methods. The study used the KCAHW (Knowledge About Childhood Autism Among Health Workers) questionnaire in the Polish language version to determine the level of autism awareness.

Results. It has been shown that the surveyed students of medical faculties (including physiotherapy) achieve lower results than students of pedagogical faculties. At the same time, students of other faculties (such as dietetics) achieve lower results than students of medical and pedagogical faculties. It has been proved that students of medical faculties achieve lower results than students of artistic and pedagogical faculties.

Conclusions. The level of knowledge about autism among students of Polish universities can be considered insufficient. Especially among medical students, i.e. future employees directly related to the diagnosis, treatment and therapy of autism.

Keywords: KCAHW, autism, ASD, knowledge.

\section{Wstęp}

Spektrum autyzmu (ASD) jako silnie heterogeniczne, neurorozwojowe zaburzenie, dotyczy deficytów w społecznej komunikacji oraz ograniczonych, powtarzających się wzorcach zachowania, zainteresowania i aktywności [1]. Charakterystyczne są tu także problemy związane z teorią umysłu [2, 3], z uczeniem się i przetwarzaniem informacji [4]. Współcześnie w Stanach Zjednoczonych szacuje się występowanie autyzmu u 1 na 45 dzieci [5].
Ze względu na nasilenie i charakter objawów towarzyszących osobie z diagnozą autyzmu, bardzo często stosuje się określenia nisko- (LFA) i wysokofunkcjonujący (HFA) autyzm. Mimo, iż nie ma żadnych formalnych kryteriów klasyfikacji do wspomnianych wyżej grup, to jednak zwykle wśród osób HFA są te w normie intelektualnej, lub powyżej niej [6].

Od kilku dekad prowadzonych jest dużo badań naukowych obejmujących grupę osób z autyzmem, mających 
na celu poznanie etiologii tak specyficznego zaburzenia. Mimo to nadal można stwierdzić, że pozostaje ona nieznana $[7,8]$. Ostatnie dwudziestolecie w badaniach zmieniło postrzeganie tegoż zaburzenia z typowo psychologicznego na obraz osoby z autyzmem jako tej, u której upośledzone są kluczowe procesy fizjologiczne, które to wpływają na powstawanie atypowych zachowań osób z ASD [1]. Zalicza się do nich nieprawidłowości na poziomie mitochondriów $[1,9]$, związane z niedoborem składników odżywczych [10-12], w tym również kwasu foliowego [13], a także z występującym stresem oksydacyjnym [14-16]. Badane są też nieprawidłowości w zakresie organizacji określonych obszarów w mózgu związanych z licznymi funkcjami poznawczymi (np. pamięć robocza, przetwarzanie języka itp.) $[16,17]$. Udowodniono także występowanie innego przewodnictwa nerwowego w mózgu osób z ASD w porównaniu do osób zdrowych [18].

Niemniej ważnym kierunkiem poszukiwań etiologii autyzmu są badania genetyczne. Nadal jednym z najbardziej nietypowych faktów pozostaje ten potwierdzony naukowo, w którym bliźnięta, a więc dzieci posiadające jednakowe DNA, nie mają 100\% współczynnika zapadalności. W przypadku bliźniąt jednojajowych prawdopodobieństwo, że oboje będą mieli autyzm sięga $88 \%$, ale u dwujajowych juz tylko 31\% [19, 20].

Autyzm pozostaje zagadkowy. Mimo niepokojącej sytuacji epidemiologicznej nadal w społeczeństwie funkcjonuje dużo stereotypów na ten temat. Jest potrzeba prowadzenia działań edukacyjnych, które przyczynić się mogą do przyspieszania diagnoz, a co za tym idzie szybkiego wprowadzania działań terapeutycznych i odpowiednio dostosowanego procesu edukacyjnego [21].

Celem pracy była ocena poziomu wiedzy o objawach autyzmu wśród studentów polskich uczelni.

\section{Materiał i metody}

W przeprowadzonym badaniu wzięło udział 446 studentów polskich uczelni wyższych z kierunków pedagogicznych (275 badanych), medycznych (109 osób) i innych (62 osoby). Grupę badaną stanowiło 410 kobiet i 36 mężczyzn w wieku od 18 do 59 lat (średnia wieku 24).

W badaniu zastosowano kwestionariusz KCAHW (Knowledge About Childhood Autism Among Health Workers) w polskiej wersji językowej (za zgodą autora), w celu określenia świadomości autyzmu. Zastosowany kwestionariusz składa się z 19 itemów i zawiera 4 skale, które obejmują różne obszary dotyczące autyzmu: obszar upośledzonych reakcji społecznych, obszar deficytów ko- munikacji i rozwoju mowy, obszar wzorców stereotypowych i zachowań kompulsywnych oraz obszar informacji o autyzmie oraz schorzeniach wspótistniejących. Stwierdzono, że kwestionariusz KCAHW wykazuje dobrą rzetelność testu-retestu, przy porównaniu średniej domeny i całkowitych wyników przy pierwszym i drugim podaniu. Cztery średnie oceny domeny i średnie całkowite wyniki przy pierwszym i drugim podaniu były istotnie skorelowane. Kwestionariusz miał również dobrą ogólną wewnętrzną spójność, gdy średnie wyniki z czterech domen były skorelowane ze średnią całkowitą punktacją (Cronbach's alpha $=0,97)$. Dane dotyczące użyteczności kwestionariusza uzyskano na drodze standaryzacji [22].

\section{Wyniki}

W celu porównania wyników uzyskanych przez respondentów na skali KCAHW wykonano obliczenia współczynników rho Spearmana, testy „t" równości średnich w grupach niezależnych, testy ANOVA oraz oszacowano istotności statystyczne uzyskanych wyników. Wybór metod i testów podyktowany był charakterem zmiennych.

Analizowane zmienne zależne to wynik całkowity kwestionariusza KCAHW oraz poszczególne skale kwestionariusza: „obszar upośledzonych reakcji społecznych”, "obszar deficytów komunikacji i rozwoju mowy”, „obszar wzorców stereotypowych i zachowań kompulsywnych" oraz "obszar informacji o autyzmie oraz schorzeniach wspótistniejących".

Zmienne niezależne, jakie wzięto pod uwagę w przeprowadzonym badaniu to: „rok studiów” oraz "rodzaj studiów”.

Wszystkie obliczenia wykonano za pomocą programu statystycznego SPSS wersja 4.0.

Analiza ANOVA ujawniła występowanie istotnych statystycznie różnic w całkowitych wynikach KCAHW ze względu na rok studiów. Stwierdzono, że badani na 2. roku studiów osiągają niższe wyniki niż badani na 4 . $(p=$ $0,000)$ oraz na 5 . roku studiów $(p=0,000)$. Jednocześnie badani na 1. roku studiów osiągają niższe wyniki niż badani na 4. $(p=0,001)$ oraz na 5. roku studiów $(p=0,017)$. Podobnie badani na 3. roku studiów osiągają niższe wyniki niż badani na $4 .(p=0,004)$ oraz na 5 . roku $(p=0,006)$

\section{(Tabela 1).}

Analiza ANOVA ujawniła również występowanie istotnych statystycznie różnic w wynikach KCAHW w obszarze upośledzonych reakcji społecznych ze względu na rok studiów. Wykazano, że badani na 2. roku studiów osiągają niższe wyniki niż badani na 4 . $(p=0,022)$ oraz na 5 . roku studiów $(p=0,010)$ (Tabela 2 ). 
Tabela 1. Wyniki KCAHW ze względu na rok studiów

\begin{tabular}{|l|c|c|c|c|} 
Rok studiów & $N$ & Średnia & Minimum & Maksimum \\
1 & 58 & $12,64 \pm 2,764$ & 7 & 19 \\
2 & 91 & $11,82 \pm 3,610$ & 3 & 17 \\
3 & 69 & $12,65 \pm 3,369$ & 0 & 18 \\
4 & 48 & $14,79 \pm 2,821$ & 6 & 18 \\
5 & 52 & $14,31 \pm 2,676$ & 8 & 19 \\
Ogółem & 318 & $13,01 \pm 3,325$ & 0 & 19 \\
\hline
\end{tabular}

Tabela 2. Wyniki KCAHW w obszarze upośledzonych reakcji społecznych ze względu na rok studiów

\begin{tabular}{|l|c|c|}
\multicolumn{1}{|c|}{ Rok studiów } & N & Średnia \\
\hline 1 & 58 & $5,84 \pm 1,542$ \\
2 & 91 & $5,73 \pm 1,808$ \\
3 & 69 & $5,91 \pm 1,892$ \\
4 & 48 & $6,65 \pm 1,509$ \\
5 & 52 & $6,69 \pm 1,351$ \\
Ogółem & 318 & $6,08 \pm 1,708$ \\
\hline
\end{tabular}

Analiza ANOVA ujawniła także występowanie istotnych statystycznie różnic w wynikach KCAHW w obszarze deficytów komunikacji i rozwoju mowy ze względu na rok studiów. Wykazano, że badani na 2. roku studiów osiągają niższe wyniki niż badani na 3 . $(p=0,043)$ oraz na 4 . roku studiów $(p=0,003)$ (Tabela 3).

Tabela 3. Wyniki KCAHW w obszarze deficytów komunikacji i rozwoju mowy ze względu na rok studiów

\begin{tabular}{|l|c|c|} 
Rok studiów & N & Średnia \\
\hline 1 & 58 & $0,71 \pm 0,459$ \\
2 & 91 & $0,62 \pm 0,489$ \\
3 & 69 & $0,81 \pm 0,394$ \\
4 & 48 & $0,90 \pm 0,309$ \\
5 & 52 & $0,79 \pm 0,412$ \\
\hline Ogółem & 318 & $0,75 \pm 0,436$ \\
\hline
\end{tabular}

Analiza ANOVA ujawniła występowanie istotnych statystycznie różnic w wynikach KCAHW w obszarze wzorców stereotypowych i zachowań kompulsywnych ze względu na rok studiów. Wykazano, że badani na 2. roku studiów osiągają niższe wyniki niż badani na $4 .(p=0,000)$ oraz na 5 . roku studiów $(p=0,000)$. Jednocześnie badani na 1. roku studiów osiągają niższe wyniki niż badani na 4 . $(p=0,000)$ oraz na 5. roku studiów $(p=0,001)$. Badani na 3. roku studiów osiągają zaś niższe wyniki niż badani na 4 . roku $(p=0,000)$ (Tabela 4$)$.

Tabela 4. Wyniki KCAHW w obszarze wzorców stereotypowych i zachowań kompulsywnych ze względu na rok studiów

\begin{tabular}{|l|c|c|} 
Rok studiów & $\mathrm{N}$ & Średnia \\
1 & 58 & $2,40 \pm 1,107$ \\
2 & 91 & $2,29 \pm 1,293$ \\
3 & 69 & $2,68 \pm 1,266$ \\
4 & 48 & $3,48 \pm 0,772$ \\
5 & 52 & $3,19 \pm 0,951$ \\
Ogółem & 318 & $2,72 \pm 1,213$ \\
\hline
\end{tabular}

Analiza ANOVA ujawniła również występowanie istotnej statystycznie różnicy w wynikach KCAHW w obszarze informacji o autyzmie i schorzeniach wspótistniejących ze względu na rok studiów. Wykazano, że badani na 2. roku studiów osiągają niższe wyniki niż badani na $1 .(p=0,023)$ oraz na 4. roku studiów $(p=0,013)$. Jednocześnie badan na 3. roku studiów osiągają niższe wyniki niż badani na 4 . roku $(p=0,030)$ (Tabela 5).

Tabela 5. Wyniki KCAHW w obszarze informacji o autyzmie i schorzeniach współistniejących ze względu na rok studiów

\begin{tabular}{|l|c|c|} 
Rok studiów & $\mathrm{N}$ & Średnia \\
1 & 58 & $3,69 \pm 1,245$ \\
2 & 91 & $3,20 \pm 1,343$ \\
3 & 69 & $3,25 \pm 1,218$ \\
4 & 48 & $3,77 \pm 1,325$ \\
5 & 52 & $3,63 \pm 1,253$ \\
Ogółem & 318 & $3,46 \pm 1,297$ \\
\hline
\end{tabular}

Analiza ANOVA ujawniła występowanie istotnej statystycznie różnicy w całkowitych wynikach KCAHW ze względu na rodzaj studiów. Wykazano, że badani studenci kierunków medycznych osiągają niższe wyniki niż studenci kierunków pedagogicznych $(p=0,000)$. Jednocześnie studenci kierunków "innych" osiągają niższe wyniki niż studenci kierunków medycznych $(p=0,000)$ oraz pedagogicznych $(p=0,000)$ (Tabela 6 ).

Tabela 6. Wyniki KCAHW ze względu na rodzaj studiów

\begin{tabular}{|l|c|c|c|c|} 
Rodzaj studiów & $\mathrm{N}$ & Średnia & Minimum & Maksimum \\
medyczne & 109 & $12,66 \pm 2,858$ & 6 & 19 \\
pedagogiczne & 275 & $14,18 \pm 2,931$ & 3 & 19 \\
artystyczne & 4 & $12,50 \pm 1,291$ & 11 & 14 \\
inżynierskie & 2 & $9,00 \pm 1,414$ & 8 & 10 \\
Inne & 53 & $10,21 \pm 3,365$ & 0 & 16 \\
Ogółem & 446 & $13,30 \pm 3,236$ & 0 & 19
\end{tabular}

Analiza ANOVA ujawniła również występowanie istotnej statystycznie różnicy w wynikach KCAHW w obszarze upośledzonych reakcji społecznych, ze względu na rodzaj studiów. Wykazano, że badani studenci kierunków medycznych osiągają niższe wyniki niż studenci kierunków pedagogicznych $(p=0,000)$. Jednocześnie studenci kierunków innych osiągają niższe wyniki niż studenci kierunków medycznych $(p=0,004)$ oraz pedagogicznych $(p=0,000)($ Tabela 7$)$.

Tabela 7. Wyniki KCAHW w obszarze upośledzonych reakcji społecznych ze względu na rodzaj studiów

\begin{tabular}{|l|c|c|} 
Rodzaj studiów & $\mathrm{N}$ & Średnia \\
medyczne & 109 & $5,85 \pm 1,660$ \\
pedagogiczne & 275 & $6,73 \pm 1,471$ \\
artystyczne & 4 & $6,50 \pm 1,291$ \\
inżynierskie & 2 & $6,00 \pm 1,414$ \\
Inne & 53 & $4,89 \pm 1,728$ \\
Ogółem & 446 & $6,28 \pm 1,673$
\end{tabular}


Analiza ANOVA ujawniła także występowanie istotnej statystycznie różnicy w wynikach KCAHW w obszarze deficytów komunikacji i rozwoju mowy, ze względu na rodzaj studiów. Wykazano, że studenci kierunków medycznych osiągają niższe wyniki niż studenci kierunków artystycznych $(p=0,000)$ oraz pedagogicznych $(p=0,045)$. Studenci kierunków artystycznych osiągają natomiast lepsze wyniki niż studenci kierunków pedagogicznych ( $p=0,000)$ (Tabela 8).

Tabela 8. Wyniki KCAHW w obszarze deficytów komunikacji i rozwoju mowy ze względu na rodzaj studiów

\begin{tabular}{|l|c|c|} 
Rodzaj studiów & $N$ & Średnia \\
medyczne & 109 & $0,66 \pm 0,476$ \\
\hline pedagogiczne & 275 & $0,81 \pm 0,389$ \\
artystyczne & 4 & $1,00 \pm 0,000$ \\
inżynierskie & 2 & $0,50 \pm 0,707$ \\
\hline Inne & 53 & $0,64 \pm 0,484$ \\
\hline Ogółem & 446 & $0,76 \pm 0,429$ \\
\hline
\end{tabular}

Analiza ANOVA ujawniła również występowanie istotnej statystycznie różnicy w wynikach KCAHW w obszarze wzorców stereotypowych i zachowań kompulsywnych, ze względu na rodzaj studiów. Wykazano, że badani studenci kierunków pedagogicznych osiągają wyższe wyniki niż studenci kierunków medycznych $(p=0,000)$ oraz innych $(p=0,000)$ (Tabela 9).

Tabela 9. Wyniki KCAHW w obszarze wzorców stereotypowych i zachowań kompulsywnych ze względu na rodzaj studiów

\begin{tabular}{|l|c|c|} 
Rodzaj studiów & $\mathrm{N}$ & Średnia \\
medyczne & 109 & $2,36 \pm 1,190$ \\
pedagogiczne & 275 & $3,18 \pm 1,013$ \\
artystyczne & 4 & $3,50 \pm 0,577$ \\
inżynierskie & 2 & $1,00 \pm 1,414$ \\
\hline Inne & 53 & $2,04 \pm 1,240$ \\
Ogółem & 446 & $2,84 \pm 1,180$ \\
\hline
\end{tabular}

Analiza ANOVA ujawniła również występowanie istotnej statystycznie różnicy w wynikach KCAHW w obszarze informacji o autyzmie i schorzeniach współistniejących ze względu na rodzaj studiów. Wykazano, że badani studenci kierunków medycznych osiągają wyższe wyniki niż studenci kierunków artystycznych $(p=0,005)$ oraz innych $(p=0,000)$. Jednocześnie studenci kierunków pedagogicznych osiągają wyższe wyniki niż studenci kierunków artystycznych $(p=0,030)$ oraz innych $(p=0,000)$ (Tabela 10).

Tabela 10. Wyniki KCAHW w obszarze informacji o autyzmie i schorzeniach wspótistniejących ze względu na rodzaj studiów

\begin{tabular}{|l|c|c|}
\hline \multicolumn{1}{|c|}{ Rodzaj studiów } & $\mathrm{N}$ & Średnia \\
medyczne & 109 & $3,79 \pm 1,139$ \\
\hline pedagogiczne & 275 & $3,45 \pm 1,290$ \\
artystyczne & 4 & $1,50 \pm 1,291$ \\
inżynierskie & 2 & $1,50 \pm 2,121$ \\
\hline Inne & 53 & $2,64 \pm 1,226$ \\
\hline Ogółem & 446 & $3,42 \pm 1,306$ \\
\hline
\end{tabular}

\section{Dyskusja}

Kwestionariusz Knowledge About Childhood Autism Among Health Workers [22] wykorzystuje się w wielu badaniach naukowych do oceny poziomu świadomości autyzmu.

Shaukat i wsp. w 2014 rok przeanalizowali wyniki ankiet wypełnionych przez 157 studentów czwartego medycyny. Grupa badana stanowiła 62 mężczyzn oraz 95 kobiet. Średni wyniki uzyskany przez studentów to 12,30 \pm 4,71 na maksymalnych 25 punktów. Autorzy tych badań zmodyfikowali pierwotną skalę poszerzając ją o ilość pytań z 19 do 25 o dodatkowe pytania dotyczące IQ oraz edukacji pacjentów autystycznych [23].

W 2011 roku poddani analizie stanu wiedzy o ASD u 80 pielęgniarek pediatrycznych i psychiatrycznych. Badanie zostało wykonane przez Igwe i wsp., a średni wynik uzyskany przez wszystkie badane osoby to $12,56 \pm 3,23$ na 19 możliwych. Wynik dla pielęgniarek pediatrycznych kształtował się na poziomie 11,78 $\pm 3,64$, natomiast dla pielęgniarek psychiatrycznych osiągnięty wynik to 13,35 \pm 2,58. Autorzy we wnioskach swojej pracy stwierdzają, że występują istotne braki w wiedzy o zaburzeniach ze spektrum wśród multidyscyplinarnego zespołu zajmującego się dziećmi z ASD. Badacze zauważają, że szersza znajomość objawów autyzmu zapewne przyczyni się do szybszego stawiania diagnozy autyzmu, co z kolei może skutkować lepszymi rokowaniami pacjentów z ASD [24].

Kolejna analiza została przeprowadzona przez Hutton i wsp. na 50 nauczycielach w 2016 roku i wykazała znajomość objawów autyzmu na poziomie 13,08 punktów na 19 możliwych. Autorzy badania dowiedli, że 68\% nauczycieli rozpoznaje objawy autyzmu, a kwestionariusz KCAHW jest użytecznym i skutecznym narzędziem. Dodatkowo stwierdzono, że pedagodzy mają dobrą znajomość ogólną ASD [25].

W 2009 roku badania przedstawione przez Bakare i wsp. zostały przeprowadzone na 134 pracownikach służby zdrowia. Średni uzyskany wynik z wypełnionych kwestionariuszy to 12,35 \pm 4,40 na maksymalnie 19 możliwych do uzyskania punktów. Bliskie istotności wyniki uzyskano u psychiatrów w porównaniu do pediatrów $(p=0,071)$. Również lepsze rezultaty pracowników służby zdrowia związane były ze stażem pracy $(p=0,056)$. Dodatkowo zauważono, że ponad połowa pracowników służby zdrowia ocenia, że stan praw i potrzeby dzieci z autyzmem (oraz z inną diagnozą zaburzeń rozwojowych) jest znacznie obniżony aniżeli oczekiwano by tego od pracowników służby zdrowia [26].

Bakare i wsp. w 2015 roku podaje, izz znajomość objawów autyzmu u przedstawicieli służby zdrowia jest ni- 
ska, czego dowodzą otrzymane przez nich wyniki badań z wykorzystaniem opisywanego narzędzia badawczego. W tym badaniu przeanalizowano znajomość objawów autyzmu u 757 studentów ostatniego roku kierunków medycznych z 10 szkół medycznych. Stwierdzono dodatkowo, że tylko $28,8 \%$ studentów uczestniczyło w badaniu dziecka z ASD podczas swoich praktyk pediatrycznych i psychiatrycznych. Wysnuto więc wniosek, że potrzeba szerszego podejmowania tematu dotyczącego autyzmu w czasie studiów medycznych, zwłaszcza w czasie praktyk pediatrycznych i psychiatrycznych [27].

Kolejnym badaniem wykorzystującym kwestionariusz KCAHW było przeprowadzone przez Eseigbe i wsp. w 2015 roku. Naukowcy analizie poddali 175 lekarzy. Zauważono, iż lekarze posiadający specjalizację uzyskali wyniki wyższe bądź równe 15 punktów w ilości 69,4% respondentów. Natomiast lekarze bez specjalizacji uzyskali wyniki większe bądź równe 15 punktów w ilości 30,6 \% osób biorących udział w badaniu. W tym badaniu wykazano również, że psychiatrzy i pediatrzy osiągali wyniki powyżej 15 punktów (19 możliwych), natomiast lekarze interniści osiągali wyniki poniżej 15 punktów [28].

W 2010 roku zespół prowadzony przez Igwe i wsp. ocenił 300 studentów ostatniego roku studiów medycznych, pielęgniarstwa i psychologii. Wynik uzyskany przez osoby poddane badaniu to $10,67 \pm 3,73$ na 19 możliwych odpowiedzi. Wyniki dla poszczególnych kierunków prezentują się następująco; medycyna 12,24 $\pm 3,24$; pielęgniarstwo $10,76 \pm 3,50$, psychologia $9,01 \pm 3,76$. Stwierdzono, że studenci medycyny częściej rozpoznają objawy autyzmu, w porównaniu do studentów pielęgniarstwa i psychologii. Autorzy w swojej publikacji podkreślili, konieczność zwrócenia szczególnej uwagi (zwłaszcza na psychologii), na naukę objawów ASD, co miałoby się przełożyć na wcześniejsze rozpoznawanie autyzmu [29].

Autorzy wymienionych badań jednogłośnie alarmują o niskim poziomie świadomości dotyczącej objawów autyzmu oraz stwierdzają, że społeczny poziom wiedzy na ten temat jest stosunkowo niski. Zwłaszcza wśród przyszłych przedstawicieli służby zdrowia, którzy są bezpośredni związani z diagnostyką dzieci z zaburzeniami rozwoju ze spektrum autyzmu.

\section{Wnioski}

Wykazano, że badani studenci kierunków medycznych osiągają niższe wyniki niż studenci kierunków pedagogicznych. Jednocześnie studenci kierunków „innych" osiągają niższe wyniki niż studenci kierunków medycznych oraz pedagogicznych.

Dowiedziono, że studenci kierunków medycznych osiągają niższe wyniki niż studenci kierunków artystycznych oraz pedagogicznych. Studenci kierunków artystycznych osiągają natomiast lepsze wyniki niż studenci kierunków pedagogicznych.

Poziom wiedzy o autyzmie wśród studentów polskich uczelni można uznać za niewystarczający. Zwłaszcza wśród studentów kierunków medycznych, czyli wśród przyszłych pracowników związanych bezpośrednio z diagnozą autyzmu.

\section{Oświadczenia}

Oświadczenie dotyczące konfliktu interesów

Autorzy deklarują brak konfliktu interesów.

\section{Źródła finansowania}

Autorzy deklarują brak źródeł finansowania.

\section{Piśmiennictwo}

1. Rossignol DA, Frye RE. A review of research trends in physiological abnormalities in autism spectrum disorders: immune dysregulation, inflammation, oxidative stress, mitochondrial dysfunction and environmental toxicant exposures. Mol Psychiatry. kwiecień 2012;17(4):389-401.

2. Pilowsky T, Yirmiya N, Arbelle S, Mozes T. Theory of mind abilities of children with schizophrenia, children with autism, and normally developing children. Schizophr Res. 7 kwiecień 2000;42(2):145-55.

3. Wallace GL, Case LK, Harms MB, Silvers JA, Kenworthy $L$ Martin A. Diminished Sensitivity to Sad Facial Expressions in High Functioning Autism Spectrum Disorders is Associated with Symptomatology and Adaptive Functioning. J Autism Dev Disord. listopad 2011;41(11):1475-86.

4. Bird G, Catmur C, Silani G, Frith C, Frith U. Attention does not modulate neural responses to social stimuli in autism spectrum disorders. Neurolmage. 15 lipiec 2006;31(4):1614-24.

5. Zablotsky B, Black LI, Maenner MJ, Schieve LA, Blumberg SJ. Estimated Prevalence of Autism and Other Developmental Disabilities Following Questionnaire Changes in the $2014 \mathrm{Na}$ tional Health Interview Survey. Natl Health Stat Rep. 13 listopad 2015;(87):1-20.

6. Barendse EM, Hendriks MP, Jansen JF, Backes WH, Hofman PA, Thoonen G, i in. Working memory deficits in high-functioning adolescents with autism spectrum disorders: neuropsychological and neuroimaging correlates. J Neurodev Disord. 4 czerwiec 2013;5(1):14.

7. Hallmayer J, Cleveland S, Torres A, Phillips J, Cohen B, Torigoe T, $i$ in. Genetic heritability and shared environmental factors among twin pairs with autism. Arch Gen Psychiatry. listopad 2011;68(11):1095-102.

8. Sandin S, Lichtenstein P, Kuja-Halkola R, Larsson H, Hultman $\mathrm{CM}$, Reichenberg A. The familial risk of autism. JAMA. 7 maj 2014;311(17):1770-7.

9. Frye RE, Rossignol DA. Mitochondrial dysfunction can connect the diverse medical symptoms associated with autism spectrum disorders. Pediatr Res. maj 2011;69(5 Pt 2):41R-7R.

10. Filipek PA, Accardo PJ, Baranek GT, Cook EH, Dawson G, Gordon $B$, $i$ in. The screening and diagnosis of autistic spectrum disorders. J Autism Dev Disord. grudzień 1999;29(6):439-84.

11. Frye RE, Melnyk S, Macfabe DF. Unique acyl-carnitine profiles are potential biomarkers for acquired mitochondrial disease in autism spectrum disorder. Transl Psychiatry. 22 styczeń 2013;3:e220 
12. Celestino-Soper PBS, Violante S, Crawford EL, Luo R, Lionel $A C$, Delaby $E$, i in. A common X-linked inborn error of carnitine biosynthesis may be a risk factor for nondysmorphic autism. Proc Natl Acad Sci U S A. 22 maj 2012;109(21):7974-81.

13. Frye RE, Sequeira JM, Quadros EV, James SJ, Rossignol DA. Cerebral folate receptor autoantibodies in autism spectrum disorder. Mol Psychiatry. marzec 2013;18(3):369-81.

14. James SJ, Melnyk S, Jernigan S, Cleves MA, Halsted CH, Wong $\mathrm{DH}, \mathrm{i}$ in. Metabolic endophenotype and related genotypes are associated with oxidative stress in children with autism. Am J Med Genet Part B Neuropsychiatr Genet Off Publ Int Soc Psychiatr Genet. 5 grudzień 2006;141B(8):947-56.

15. Rose S, Melnyk S, Pavliv O, Bai S, Nick TG, Frye RE, i in. Evidence of oxidative damage and inflammation associated with low glutathione redox status in the autism brain. Transl Psychiatry. 10 lipiec 2012;2:e134.

16. Anderson JS, Nielsen JA, Froehlich AL, DuBray MB, Druzgal TJ, Cariello $A N, i$ in. Functional connectivity magnetic resonance imaging classification of autism. Brain J Neurol. grudzień 2011;134(Pt 12):3742-54.

17. Cherkassky VL, Kana RK, Keller TA, Just MA. Functional connectivity in a baseline resting-state network in autism. Neuroreport. 6 listopad 2006;17(16):1687-90.

18. Monk CS, Peltier SJ, Wiggins JL, Weng S-J, Carrasco M, Risi $S$, i in. Abnormalities of intrinsic functional connectivity in autism spectrum disorders. Neurolmage. 15 sierpień 2009;47(2):764-72.

19. Rosenberg RE, Law JK, Yenokyan G, McGready J, Kaufmann WE, Law PA. Characteristics and concordance of autism spectrum disorders among 277 twin pairs. Arch Pediatr Adolesc Med. październik 2009;163(10):907-14.

20. Newschaffer CJ, Croen LA, Fallin MD, Hertz-Picciotto I, Nguyen DV, Lee NL, i in. Infant siblings and the investigation of autism risk factors. J Neurodev Disord. 18 kwiecień 2012;4(1):7.

21. Hotez E, Shane-Simpson C, Obeid R, DeNigris D, Siller M, Costikas $C_{\text {, }}$ i in. Designing a Summer Transition Program for Incoming and Current College Students on the Autism Spectrum: A Participatory Approach. Front Psychol. 2018;9:46.

22. Bakare MO, Ebigbo PO, Agomoh AO, Menkiti NC. Knowledge about childhood autism among health workers (KCAHW) questionnaire: description, reliability and internal consistency. Clin Pract Epidemiol Ment Health CP EMH. 6 czerwiec 2008;4:17

23. Shaukat F, Fatima A, Gulamhussein MA, Zehra N. Assessment of knowledge about childhood autism among medical students from private and public universities in Karachi. J Pak Med Assoc. 2014;64(11).
24. Igwe MN, Ahanotu AC, Bakare MO, Achor JU, Igwe C. Assessment of knowledge about childhood autism among paediatric and psychiatric nurses in Ebonyi state, Nigeria. Child Adolesc Psychiatry Ment Health. 9 styczeń 2011;5:1.

25. Hutton NK, Mitchell C, Riet M van der. Assessing an isizulu questionnaire with educators in primary schools in Pietermaritzburg to establish a baseline of knowledge of Autism Spectrum Disorder. BMC Pediatr. 1 grudzień 2016;16(1):185.

26. Bakare MO, Ebigbo PO, Agomoh AO, Eaton J, Onyeama GM, Okonkwo KO, i in. Knowledge about childhood autism and opinion among healthcare workers on availability of facilities and law caring for the needs and rights of children with child hood autism and other developmental disorders in Nigeria. BMC Pediatr. 12 luty 2009;9:12.

27. Bakare MO, Tunde-Ayinmode MF, Adewuya AO, Bello-Mojeed MA, Sale S, James BO, i in. Recognition of Autism Spectrum Disorder (ASD) symptoms and knowledge about some other aspects of ASD among final year medical students in Nigeria, Sub-Saharan Africa. BMC Res Notes. 18 wrzesień 2015;8:454.

28. Eseigbe EE, Nuhu FT, Sheikh TL, Eseigbe P, Sanni KA, Olisah VO Knowledge of Childhood Autism and Challenges of Management among Medical Doctors in Kaduna State, Northwest Nigeria [Internet]. Autism Research and Treatment. 2015 [cytowane 9 luty 2018]. Dostępne na: https://www.hindawi. com/journals/aurt/2015/892301/

29. Igwe MN, Bakare MO, Agomoh AO, Onyeama GM, Okonkwo KO. Factors influencing knowledge about childhood autism among final year undergraduate Medical, Nursing and Psychology students of University of Nigeria, Enugu State, Nigeria. Ital J Pediatr. 13 czerwiec 2010;36:44.

Zaakceptowano do edycji: 20.08.19 Zaakceptowano do publikacji: 26.09.19

Adres do korespondencji:

Piotr Poniewierski

Klinika i Katedra Reumatologii i Rehabilitacji

ul. 28 czerwca 1956 r. 135/147

61-545 Poznań

tel. 618310244

e-mail: piotrponiewierski@wp.pl 